\title{
Assessment of Clayey Raw Materials from the Argillic Alteration Zones from Sappes Area, Thrace, Northern Greece in Ceramic Production ${ }^{\dagger}$
}

\author{
Eleni Koutsopoulou ${ }^{1, *(\mathbb{D})}$, Ioannis Marantos ${ }^{1}$, Vayia Xanthopoulou ${ }^{2,3} \mathbb{D}$, Nikolaos Xirokostas ${ }^{1,4}$ \\ and Ioannis Iliopoulos 2 (D)
}

1 Hellenic Survey of Geology and Mineral Exploration (HSGME), GR-13677 Athens, Greece; yanmarantos@igme.gr (I.M.); nxirokostas@igme.gr (N.X.)

2 Department of Geology, University of Patras, GR-26500 Patras, Greece; vxanthopoulou@upatras.gr (V.X.); ilios@upatras.gr (I.I.)

3 Laboratory of Electron Microscopy and Microanalysis, School of Natural Sciences, University of Patras, GR-26500 Patras, Greece

4 Ministry of Environment and Energy, GR-11523 Athens, Greece

* Correspondence: ekoutsop@upatras.gr or ekoutsopoulou@igme.gr

+ Presented at International Conference on Raw Materials and Circular Economy, Athens, Greece, 5-9 September 2021.

check for updates

Citation: Koutsopoulou, E.; Marantos, I.; Xanthopoulou, V.; Xirokostas, N.; Iliopoulos, I. Assessment of Clayey Raw Materials from the Argillic Alteration Zones from Sappes Area, Thrace, Northern Greece in Ceramic Production. Mater. Proc. 2021, 5, 114. https://doi.org/ $10.3390 /$ materproc2021005114

Academic Editor: Evangelos Tzamos

Published: 15 February 2022

Publisher's Note: MDPI stays neutral with regard to jurisdictional claims in published maps and institutional affiliations.

Copyright: (C) 2022 by the authors. Licensee MDPI, Basel, Switzerland. This article is an open access article distributed under the terms and conditions of the Creative Commons Attribution (CC BY) license (https:// creativecommons.org/licenses/by/ $4.0 /)$.

\begin{abstract}
Samples were collected from the argillic alteration zones in Sappes area, Thrace, Northern Greece and were examined for their mineralogical composition. Results showed that the sericite zone is the most widespread type of alteration in the studied area, followed by the transitional sericitekaolinite zone and finally the pyrophyllite-rich zone. After determination of the spatial distribution of the different argillic alteration zones, selected samples were examined for their technological ceramic properties in order to evaluate their use in ceramic production. Preliminary results showed that after beneficiation processes, the clayey raw material from the alteration zones could be used in the ceramic industry.
\end{abstract}

Keywords: argillic alteration zones; ceramic properties; sericite; kaolinite; pyrophyllite

\section{Introduction}

The Sappes area is located at the border of Essimi-Kirki and Sappes-Komotini Tertiary basins. The area is covered by volcaniclastic rocks and lavas of intermediate composition, sub volcanic intrusive rocks (dacites-andesites) and plutonic rocks (quartz monzodiorite). The above formations have been strongly altered as a result of intense hydrothermal activity. Based on preliminary results in the study area conducted by the Hellenic Survey of Geology and Mineral Exploration, HSGME (former IGME), the following alteration zones have been identified: (a) siliceous zone, (b) alunite zone, (c) sericite/argillic zone, (d) kaolinite zone, and (e) pyrophyllite zone [1-3].

Similar deposits formed by hydrothermal alteration of intrusive rhyolite have been widely used as ceramic argillaceous raw materials in Japan since the 17th century [4]. They are usually of Quaternary or Tertiary age and are referred to as Toseki or Roseki clays (porcelain or pottery stone deposits). Toseki clays are composed mainly of sericite; kaolinite and quartz and Roseki consist mainly of pyrophyllite, kaolinite with or without sericite and quartz [4-7]. Kaolin deposits formed by hydrothermal alteration of rhyo-andesite is also classified as Roseki in Japan, even though it is composed mainly of kaolinite [4]. In Sardinia, Italy, kaolinitic clays associated with Oligo-Miocene calcalkaline andesitesrhyolites have found applications in the ceramic industry. These volcanogenic kaolinites are mainly composed of kaolinite, silica phases (quartz and cristobalite) and minor smectite and have been used as components in whiteware production $[8,9]$. 
In the present contribution extended petrographic, mineralogical and geochemical studies have led to the determination of the spatial distribution of the "argillic" alteration zones in the area and the detailed description of the mineral assemblages present in the aforementioned zones. In the term "argillic" we include the sericite zone, which is the most prevalent type of alteration in the study area, the transitional sericite-kaolinite zone which is found either as sericite-rich or kaolinite-rich assemblages and the pyrophyllite-rich altered rocks. Samples from the argillic alteration zones were also examined for their technological properties in an attempt to evaluate their ceramic behavior and their potential use in the ceramic industry.

\section{Materials and Methods}

Overall 70 samples were collected from the Tertiary basins of Sappes area, Thrace, NE Greece. All samples were analyzed for the determination of their mineralogical composition with X-ray diffraction (XRD) using a Panalytical X'pert-Pro X-ray diffractometer, $\mathrm{Cu}-\mathrm{K} \alpha$ radiation, graphite monochromator, $30 \mathrm{kV}$ and $40 \mathrm{~mA}$. The random powder mounts of samples were scanned from 2 to $70^{\circ} 2 \theta$, with a scanning step $2 \theta^{\circ}=0.01^{\circ}$ and 3 s scanning time per step. The $<2 \mu \mathrm{m}$ clay fraction was separated by settling and dried on glass slides at room temperature. The glass slides were ethylene glycol (EG) solvated at $60{ }^{\circ} \mathrm{C}$ overnight. XRD analysis was performed from 2 to $35^{\circ} 2 \theta$, scanning step $2 \theta^{\circ}=0.03^{\circ}$ and step time $\mathrm{t}=5 \mathrm{~s}$.

After determination of the spatial distribution of the different argillic alteration zones, three composite samples were prepared for the examination of the technological properties (one for each alteration zone). The composite samples for the technological tests were prepared by mixing two or three different samples from each alteration zone: (a) the sericite zone (illite sample), (b) the transitional sericite-kaolinite zone (illite-kaolinite sample) and (c) the pyrophyllite-rich altered zone. The samples were ground, split, homogenized and analyzed for their mineralogical composition with XRD. Particle size analysis was performed using a Malvern Mastersizer 2000. The Atterberg limits (liquid limit, LL and plastic limit, PL) were determined using the Casagrande cup.

Experimental briquettes were made from each of the mixed samples, in order to examine their microstructure and their consistency after firing. The briquettes were left to dry for a week at room temperature and then were fired at $120{ }^{\circ} \mathrm{C}$ (at a rate of $4{ }^{\circ} \mathrm{C} / \mathrm{min}$ ), for $1 \mathrm{~h}$ at soaking temperature. The color of the briquettes was recorded based on Munsell Chart Colors. The briquette made from the sericite zone (illitic raw material) had a very pale brown color (10YR 8/3) and obtained a white pale yellow color (2.5Y 8/1-8/2) after firing (Figure 1). The sample from the sericite-kaolinite zone (illitic+kaolinitic raw material) gave a light gray (10YR 7/2) color in the wet state of the briquette and a white $(2.5 Y 8 / 1)$ color after firing. The raw material from the pyrophyllite-rich altered zone had a light gray-white (10YR 7/1-8/1) color at the wet state and after firing a white color (gley $18 / \mathrm{N}$ ). All the studied experimental briquettes were in a good condition after firing, showing consistency and no cracking.

For the study of the microstructure and textural characterization, the observation was made on pieces of fresh fractured surfaces obtained from the briquettes (after firing at $1200{ }^{\circ} \mathrm{C}$ ) by using a pinch or a chisel. The microstructural analysis was performed on gold coated fresh fractures of the fired briquettes using a JEOL 6300 SEM in the Laboratory of Electron Microscopy and Microanalysis at the University of Patras, Greece. 


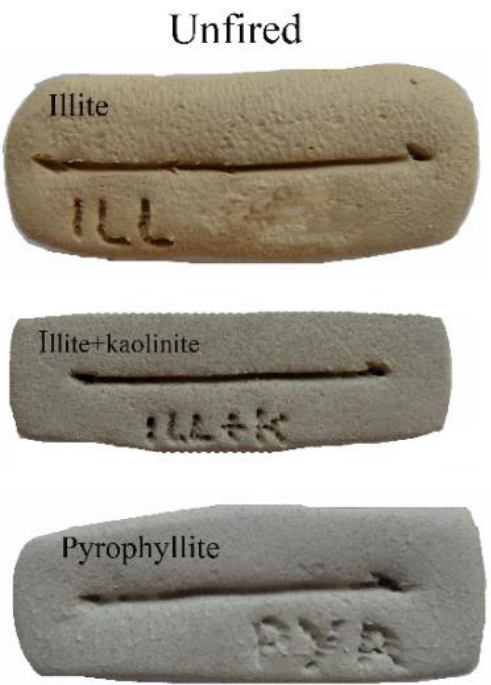

(a)
Fired at $1200^{\circ} \mathrm{C}$
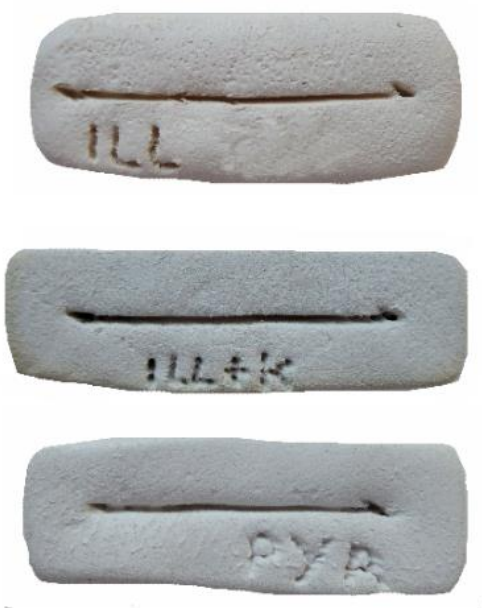

(b)

Figure 1. Experimental briquettes from the studied samples (a) in the unfired state and (b) after firing at $1200{ }^{\circ} \mathrm{C}$.

\section{Results and Discussion}

\subsection{Mineralogical and Petrographical Characteristics}

X-ray diffraction patterns of random powder mounts and optical microscopy results revealed the mineralogy of the argillic alteration zones. The samples from Sappes area are generally characterized by the presence of illite, kaolinite, quartz, and pyrophyllite. In general, the sericite zone is the most widespread type of alteration in the studied area, followed by the transitional sericite-kaolinite zone and finally the pyrophyllite-rich zone. The sericite zone is mainly composed of sericite (illite), and quartz with occasionally minor kaolinite. The transitional sericite-kaolinite zone is encountered either as sericiterich or kaolinite-rich assemblages in the study area and is mainly composed of sericite and kaolinite-in variable contents-and quartz. The pyrophyllite-rich zone is mainly composed of pyrophyllite with or without kaolinite and quartz. In some of the samples minor sericite is also present. Sericite content ranges from about $54 \%$ in the sericite zone to very low in the kaolinite and pyrophyllite rich assemblages (approximately $2 \%$ ), kaolinite ranges from 13 to $55 \%$ in the transitional sericite-kaolinite zone and pyrophyllite reaches up to $68 \%$ in the pyrophyllite-rich zone. Traces of rutile, alunite and/or jarosite may also be present in the samples from all alteration zones.

The examination of the samples under polarizing microscope showed that the primary texture has been destroyed while the phenocrysts have been completely replaced by fine-grained clay alteration (Figure 2). Sericite is replacing feldspar phenocrysts usually as fine-grained aggregates or in places as needlelike fine-grained crystals or in patchy anomalous brown clasts. Kaolinite is found as fine-grained aggregates or compact masses and pyrophyllite is present as fine-grained foliated laminae, rarely massive. Locally, cavities consisting of microcrystalline quartz and sericite indicate that there were multiple fluid events. Interlocking, anhedral quartz also fills cavities. 


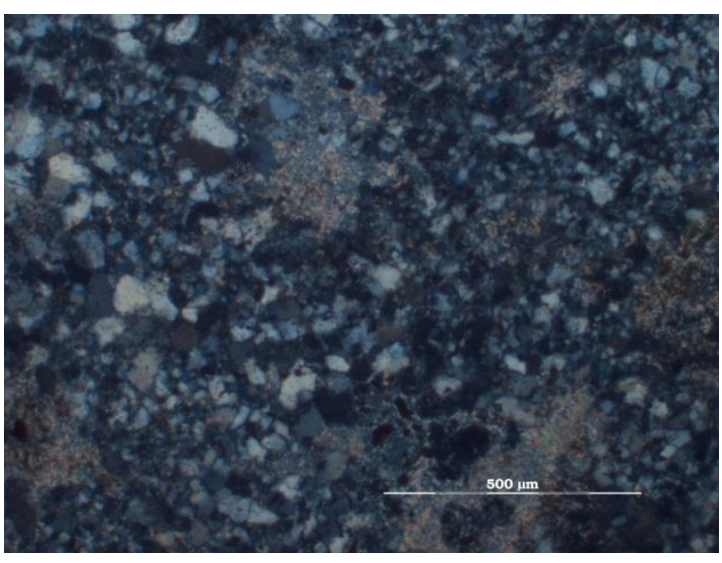

(a)

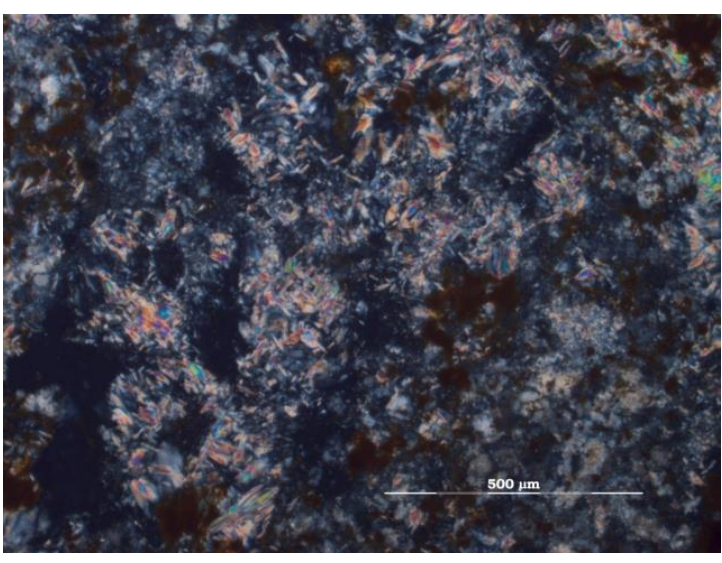

(b)

Figure 2. Representative photomicrographs from thin sections of the samples from the argillic alteration zones under crossed polars: (a) relics of feldspar crystals that have been completely replaced by clay alteration (sericite, kaolinite) from the transitional sericite-kaolinite zone. Quartz is fine grained in masses often with undulose extinction; (b) pyrophyllite as well-defined fine-grained foliated laminae or in fine-grained masses together with kaolinite (low 1st order gray colors) (from the pyrophyllite-rich zone). Dark brown patches in Figure $2 \mathrm{~b}$ are jarosite crystals.

X-ray diffraction patterns of the $<2 \mu \mathrm{m}$ fraction of samples collected from the studied area from all the argillic alteration zones are shown in Figure 3 . The clay fraction $(<2 \mu \mathrm{m})$ of the samples is clearly dominated by illite in the sericite zone, illite and kaolinite in the samples from the transitional sericite-kaolinite zone and pyrophyllite and kaolinite ( \pm illite) in the pyrophyllite-rich zone.

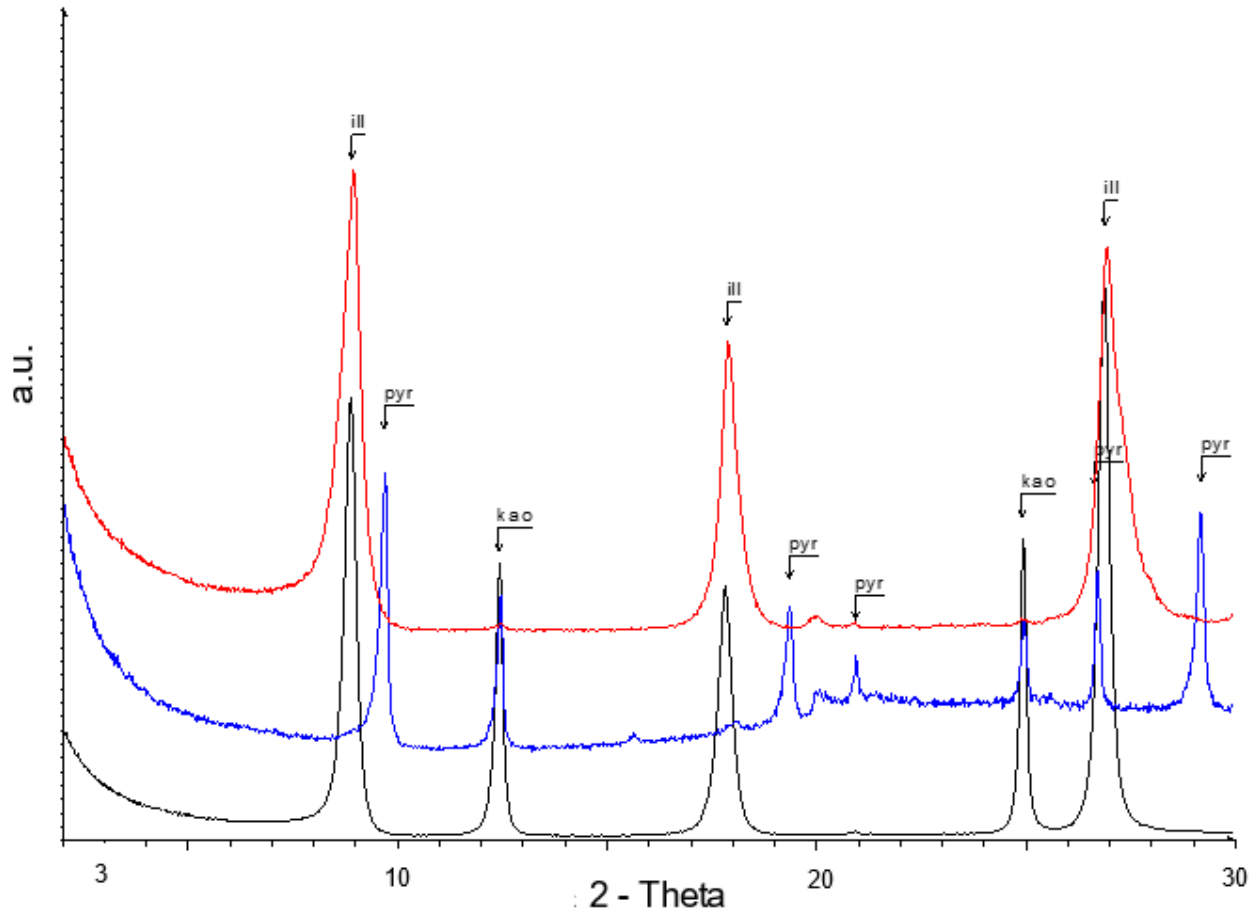

Figure 3. X-ray diffraction patterns of the $<2 \mu \mathrm{m}$ fraction of the samples. ill: illite, kao: kaolinite, pyr: pyrophyllite (red line: sericite zone, blue line: pyrophyllite-rich zone, black line: transitional sericite-kaolinite alteration zone). 


\subsection{Physical and Technological Properties}

The liquid limit $\left(\mathrm{LL}\right.$ or $\left.\mathrm{W}_{\mathrm{L}}\right)$ and the plastic limit $\left(\mathrm{PL}\right.$ or $\left.\mathrm{W}_{\mathrm{p}}\right)$ were measured for the three "mixed" samples produced by the mixing of samples from the sericite zone (illite sample), the transitional sericite-kaolinite zone (illite-kaolinite sample) and the pyrophyllite-rich altered zone. The value of the plasticity index (Ip) was calculated as the difference between the liquid limit and the plastic limit. The plasticity of most of the samples showed an average Ip which ranges between $\sim 2 \%$ and $10 \%$.

The values obtained for LL and the Ip were plotted on the modified Casagrande's plasticity chart by Holtz and Kovacs [10]. Figure 4a shows that the studied samples are plotted in the area below line A (representing a boundary between clay-like materials and silty materials) and under the boundary line of 50 (representing the boundary between low and high liquid limits). Thus, the samples from the sericite zone (illite sample) and the transitional sericite-kaolinite zone (illite-kaolinite sample) evaluated here are characterized as moderate plastic clays, whereas pyrophyllite is characterized as a low plastic clay. Similarly, the plotting of the values obtained for the PL and Ip on the plasticity chart proposed by Bain and Highley [11] and later modified by Marsigli and Dondi [12] (Figure 4b) shows that the analyzed raw materials are classified as poorly plastic clays, whilst the pyrophyllite-rich sample is characterized as poorly plastic with a quite low plasticity index ( 2 wt.\%).

The differences in the plasticity of the studied samples are highly related to the differences in their mineralogical composition and particularly the abundance of kaolinite and pyrophyllite. Kaolin deposits of similar origin have low plasticity mainly due to their larger particle size; however, they are widely used in the manufacture of ceramics as they offer whiteness to the body [13]. Mixtures of kaolinite with fine-grained sericite (illite) are traditionally used in ceramics [14] such as white porcelain [6,7] and porcelain stoneware tiles [15]. In general, the addition of illite provides plasticity in the mixture and acts as a fluxing agent $[7,15]$. Pyrophyllite clays (roseki clays), although they present low plasticity, are widely used in ceramics, as pyrophyllite has excellent volume stability, decreases thermal expansion and offers resistance to deformation at high temperatures $[7,16,17]$.

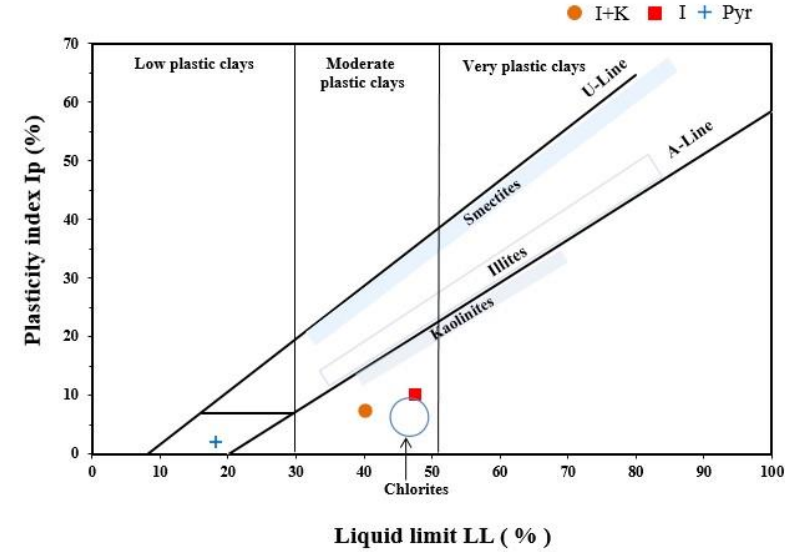

(a)

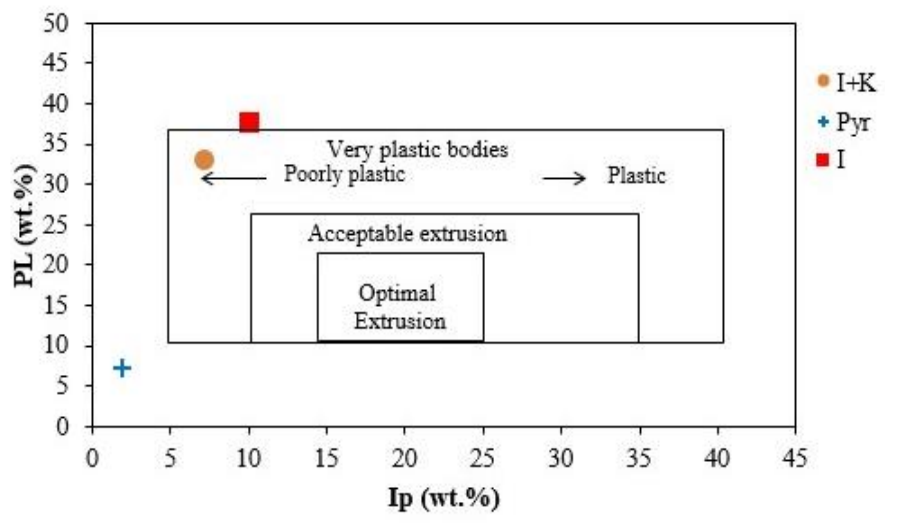

(b)

Figure 4. (a) Plot of the studied samples and the common clay minerals on the Casagrande's Plasticity chart after [10], and (b) Classification of molding behavior using plastic limits (PL) and plasticity index (Ip) values (after [12]). I: illite sample (sericite zone), I+K: illite+kaolinite sample (transitional sericite-kaolinite zone), Pyr: pyrophyllite sample (pyrophyllite-rich zone).

\subsection{Microstructure}

The textural characterization of pieces after firing was observed in a fractured surface from the briquettes. The examination of the microstructure using SEM showed the formation of large spherical pores and an extensive vitrification for the briquette made from the sericite zone (illitic raw material) after firing at $1200{ }^{\circ} \mathrm{C}$ (Figure 5a). The briquette made 
from the sericite-kaolinite zone (illitic+kaolinitic raw material) exhibited differences in the microstructure after firing. A higher percentage of small pores are observed and locally large spherical pores have been formed (Figure $5 \mathrm{~b}$ ). The briquette made from the pyrophyllitic raw material shows an extensive vitrification with the formation of few irregular pores (Figure 5c).

The variations in the microstructure of the different fired samples are consistent with their mineralogical composition with respect to the different content of illite in the studied raw materials (for the illitic and the illitic+kaolinitic raw material). This is expected inasmuch as illite acts as a fluxing agent and enhances the formation of large pores at the surface of the body [15] which is a desirable characteristic in ceramics (closed porosity). On the contrary, increased contents of pyrophyllite as in the present case result in early vitrification [18] although eventually they lead to an improvement of the thermo-mechanical properties of the specimens [17].
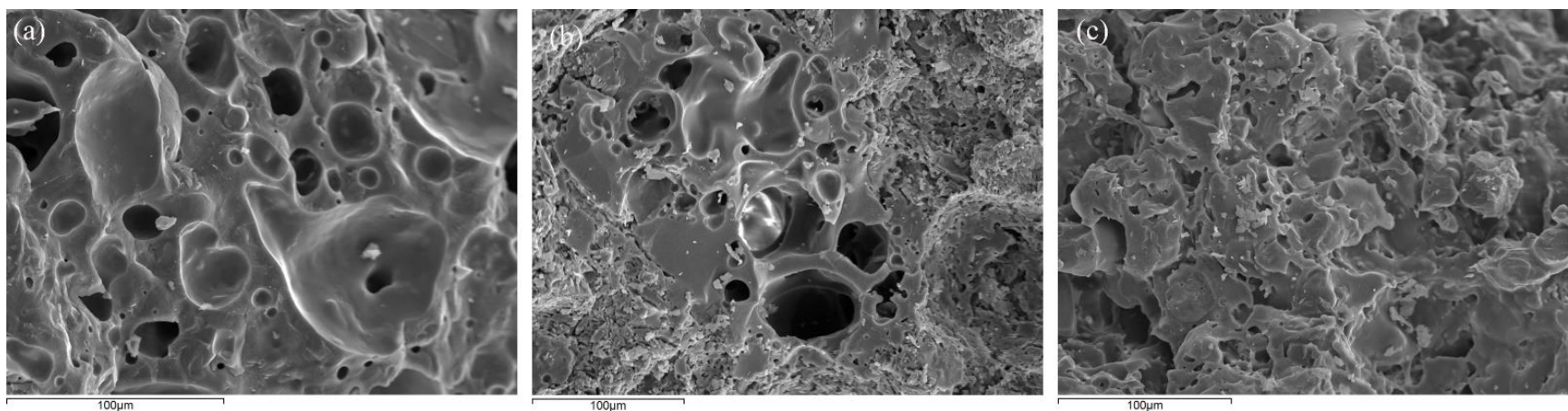

Figure 5. SEM images of fractured surfaces from the briquettes after firing at $1200{ }^{\circ} \mathrm{C}$. (a) Sericite zone; (b) transitional sericite-kaolinite zone; (c) pyrophyllite-rich zone.

\section{Conclusions}

The alteration zones that have been identified in the Sappes area, Thrace, Northern Greece are: (a) siliceous zone, (b) alunite zone, (c) sericite/argillic zone, (d) kaolinite zone, and (e) pyrophyllite zone. Detailed mineralogical, petrographic and geochemical studies have led to the determination of the spatial distribution of the argillic alteration zones and the description of the mineral assemblages present in the alteration zones. Selected samples from the alteration zones were also examined for their technological ceramic properties. Preliminary results showed that after beneficiation processes, the clayey raw material from the studied argillic alteration zones could be considered for exploitation for the ceramic industry. Future research should be focused on the chemical-mineralogical and technological assessment and the behavior in the ceramic working cycle to confirm this possibility.

Author Contributions: Conceptualization, E.K. and I.M.; methodology, E.K., I.M., V.X. and N.X.; software, E.K. and V.X.; validation, E.K., I.M. and V.X.; formal analysis, E.K., I.M., V.X.; investigation, E.K., I.M., V.X.; resources, I.M. and I.I.; data curation, E.K., I.M., V.X.; writing-original draft preparation, E.K. and V.X.; writing-review and editing, E.K., I.M. and V.X.; visualization, E.K., I.M. and V.X.; supervision, I.M. and I.I.; project administration, I.M.; funding acquisition, I.M. All authors have read and agreed to the published version of the manuscript.

Funding: This work was based on the research project: 'Evaluation of Industrial Minerals for Industrial-Technological Applications' which is part of the project: 'Exploration and Evaluation of Selected Indigenous non-metallic Mineral Raw Materials', funded by the National Strategic Reference Framework (NSRF) 2014-2020, MIS 5003300.

Institutional Review Board Statement: Not applicable.

Informed Consent Statement: Not applicable.

Data Availability Statement: Not applicable. 
Conflicts of Interest: The authors declare no conflict of interest.

\section{References}

1. Marantos, I.; Michael, C.; Perdikatsis, V. Preliminary study of weathered volcanics in the Sappes area, Rodopi region for industrial minerals. Bull. Geol. Soc. Greece 1992, 28, 317-328.

2. Michael, C.; Papadopoulos, P.; Marantos, I.; Evangelou, E. Epithermal Gold Mineralisation in Konos Area; Technical Report; I.G.M.E.: Xanthi, Greece, 1998; pp. 1-26.

3. Michael, C. Epithermal systems and gold mineralization in Western Thrace (North Greece). Bull. Geol. Soc. Greece 2004, 36, 416-423. [CrossRef]

4. Nakagawa, M. Clay mineral associations and mineralogical properties of quartz in some pottery stones of western Kyushu, Japan. Appl. Clay Sci. 1994, 8, 331-347. [CrossRef]

5. Sugiura, S.; Nakano, H.; Oya, I.; Nakayama, H. Mineralogical study of some Toseki ores (poor quality) in the Nomi Mountains, Ishikawa Prefecture, Japan. Sci. Rep. Kanazawa Univ. 1966, 11, 125-131.

6. Sudo, T. Clay Mineral Work Proceeding in Japan. Clays Clay Miner. 1955, 4, 185-195. [CrossRef]

7. Sudo, T. An outline of clays and clay minerals in Japan. In Developments in Sedimentology: Clays and Clay Minerals of Japan; Sudo, T., Shimoda, S., Eds.; Kodansha Ltd.: Tokyo, Japan; Elsevier, Scientific Publishing Company: Amsterdam, The Netherlands, 1978; Volume 26, pp. 1-33.

8. Dondi, M. Kaolinitic clays of volcanic origin: Composition, technological properties and problems in ceramic applications. In Proceedings of the 1st Latin American Clay Conference, Funchal, Portugal, 17-22 September 2000; Volume II, pp. $219-224$.

9. Dondi, M.; Guarini, G.; Ligas, P.; Palomba, M.; Raimondo, M. Chemical, mineralogical and ceramic properties of kaolinitic materials from the Tresnuraghes mining district. Appl. Clay Sci. 2001, 18, 145-155. [CrossRef]

10. Holtz, D.R.; Kovacs, D.W. An Introduction to Geotechnical Engineering; Prentice-Hall, Inc.: Englewood Cliffs, NJ, USA, 1981; pp. 10-107.

11. Bain, J.A.; Highley, D.E. Regional Appraisal of Clay Recourses; a challenge to the clay mineralogist. In Developments in Sedimentology: International Clay Conference; Mortland, M.M., Farmer, V.C., Eds.; Elsevier: Amsterdam, The Netherlands, 1978; Volume 27, pp. 437-446.

12. Marsigli, M.; Dondi, M. Plasticita delle argille italiane per laterizi e previsione del loro comportamento in foggiatura. L'Industria dei Laterizi 1997, 46, 214-222.

13. Bloodworth, A.J.; Highley, D.E.; Mitchell, C.J. Industrial Minerals Laboratory Manual_Kaolin; Technical Report; British Geological Survey WG/93/1; Natural Environment Research Council: Nottingham, UK, 1993; pp. 1-76.

14. Aras, A. The change of phase composition in kaolinite- and illite-rich clay-based ceramic bodies. Appl. Clay Sci. 2004, 24, 257-269. [CrossRef]

15. Ferrari, S.; Gualtieri, A.F. The use of illitic clays in the production of stoneware tile ceramics. Appl. Clay Sci. 2006, 32, 73-81. [CrossRef]

16. Dondi, M.; Raimondo, M.; Zanelli, C. Clays and bodies for ceramic tiles: Reappraisal and technological classification. Appl. Clay Sci. 2014, 96, 91-109. [CrossRef]

17. Mukhopadhyay, T.K.; Ghatak, S.; Maiti, H.S. Pyrophyllite as raw material for ceramic applications in the perspective of its pyro-chemical properties. Ceram. Int. 2010, 36, 909-916. [CrossRef]

18. Mukhopadhyay, T.K.; Ghatak, S.; Maiti, H.S. Effect of pyrophyllite incorporation in porcelain composition on mechanical properties and microstructure. Ceram. Int. 2009, 35, 2555-2562. [CrossRef] 